\title{
THE INFLUENCE OF SPECIFIC ACCOUNTING DIFFERENCES ON THE CHOICE BETWEEN IFRS OR US GAAP
}

\author{
Sofie Van der Meulen \\ Ann Gaeremynck \\ Marleen Willekens*
}

\begin{abstract}
Due to the increased competition on capital markets and given the global importance of US markets, IFRS and US GAAP are competing to become the world standards set. Although comparable in many aspects, IFRS and US GAAP still differ in accounting for some transactions. This paper addresses the question whether specific accounting differences between IFRS and US GAAP determine the individual firm's accounting standard preference. The results show that firms prefer that accounting regime that offers them the largest flexibility (i.e. less disclosure or more measurement options) on relevant accounting items (e.g. R\&D expenditures). Furthermore, the flexibility in measurement seems to result in accounting numbers that are significantly valued by investors.
\end{abstract}

\section{Keywords:}

accounting differences, accounting regime choice, earnings quality

\footnotetext{
* Sofie Van der Meulen is doctoral student at the KULeuven while Ann Gaeremynck and Marleen Willekens are Associate Professors at the KULeuven.

We are grateful to L. Van de Gucht, R. Knechel and B. Rees for suggestions and remarks on previous versions of this paper. We also acknowledge the comments of participants at the 2004 UvT Accounting Seminar in Tilburg, the 2004 Annual Conference in Prague, the 2004 Midyear International Financial Accounting Conference of the AAA in San Diego and the Accounting Workshop Day at the University of Amsterdam.

E-mail: s.vandermeulen@uvt.nl
} 


\section{INTRODUCTION}

In addressing the increasing cross-border dimension of investments, many European equity market regulators currently allow registrants to apply IFRS as an alternative to domestic standards (e.g. Austria, Belgium, Finland and Germany). The decision by the European Commission to require all companies listed on EU stock exchanges to prepare their financial statements in accordance with IFRS by 2005 further highlights the increased support for IFRS. In becoming a world standard, IFRS is however in fierce competition with another accounting standard set, US GAAP. In some markets, both IFRS and US GAAP are even in direct competition (like on the German New Market). Inevitably, the strive for world leadership has led to a debate on which standards are the best, not in the slightest fed by the SEC's persistence to demand a US GAAP reconciliation by US listed, foreign firms that apply IFRS.

The quality debate also raises the question as to what determines a firm's choice between IFRS and US GAAP. Similar to understanding the choices that are made within a standard set (e.g., LIFO versus FIFO), it is important to document factors that influence/determine the standard set choice.

Previous studies (e.g., Ashbaugh 2001; El-Gazzar et al. 1999) have most often looked at standard set choice from an investor's perspective. Since (outside) investors typically discount firm value for a lack of (transparent) information, it is argued that firms can benefit from choosing more transparent accounting standards (through a reduction in the cost of capital). Therefore, these studies contend that investor characteristics are typically taken into consideration when choosing an accounting standards set. Empirical evidence has, for example, found that larger firms with more diverse and geographically dispersed investors, where the information demand by investors is high and broad, often voluntarily switch from their local to a non-local GAAP (Ashbaugh 2001).

The major contribution of the current study is that, instead of focusing on the investor side, we look at the companies themselves and investigate whether the incremental discretion offered within a standard set (relative to another set) over relevant accounting areas determines the accounting standard choice. Do firms prefer IFRS because there are more opportunities to capitalize certain costs such as development costs? Do they prefer US GAAP because acquisitions can be accounted for more freely? Those 
considerations are important as they impact reported earnings, which in turn can influence the perceptions of investors.

As the results of our study show, these accounting differences are indeed important when a firm has the choice between IFRS and US GAAP. Since capitalization of development costs is, for example, possible under IFRS and not under US GAAP, firms with large R\&D expenditures are more likely to adopt IFRS. Similarly, IFRS leaves more discretion to management when accounting for share option plans, resulting in relatively more firms with share option schemes to choose IFRS. By contrast, firms that are highly active in the field of acquisitions and mergers are more likely to adopt US GAAP due to the multiple accounting alternatives offered by US GAAP on that issue.

Given that these accounting differences determine the choice for IFRS or US GAAP, two questions can be raised. Firstly, do firms use the offered flexibility to better inform investors? And secondly, is there any value attached to reporting flexibility? Looking specifically at the flexibility IFRS offers with regard to R\&D capitalization, we find that the accounting treatment of R\&D expenditures increases earnings' ability to explain returns/prices.

The remainder of this paper is organized as follows. In the next section, we first review the existing literature on accounting regime choice. Hypotheses are developed in section 3, while the model is further specified in section 4 . Next, we describe the sample and data collection procedure, followed by both univariate and multivariate results presented in section 6 . In section 7, we perform additional tests on the use and value of accounting flexibility and finally, we conclude by giving some final remarks in the conclusions section. 


\section{LITERATURE REVIEW}

However scarce, the literature on standards set choice can be grouped into three areas: research on (1) the voluntary switch from local GAAP to IFRS (2) the voluntary switch from local GAAP to either IFRS or USGAAP and (3) the choice between IFRS and USGAAP.

The first studies to address the issue of voluntary adoption of IFRS typically assume that managers are lead by investors' preference for non-local GAAP as it results in more transparent and standardized information1. They find that investor characteristics such as size and having multiple listings (proxying for investor structure) are in a positive relation to the decision to adopt IFRS (Dumontier and Raffournier 1998, El-Gazzar et al. 1999), while the financing policy (i.e., debt to equity ratio) appears to be in negative relation (El-Gazzar et al. 1999). In addition, they find that the international character of the firm, either measured by the percentage of international sales or by the percentage of foreign operations, is positively related to IFRS adoption. Finally, firms coming from a country that is a member of geographical and trade blocks in EU are more likely to apply IFRS.

Next, we identify studies that consider both IFRS and US GAAP as opposed to local GAAP (Ashbaugh 2001, Cuijpers et al. 2002). Similar to the studies discussed above, it is found that the likelihood of using a non-local GAAP is increasing in the firm's (relative) size, in the number of foreign equity markets on which the firm's shares are traded and in the geographical dispersion of operations. In addition, being listed on a US exchange or on Nasdaq Europe and planning to issue stock in the following years more frequently leads to the usage of non-local GAAP. They also find an important impact of country characteristics. Firms are more likely to depart from local GAAP when IFRS is explicitly allowed as an alternative to local GAAP in that country and when there are a large number of disclosure and measurement differences between local and non-local GAAP.

\footnotetext{
${ }^{1}$ Editing financial statements according to a world GAAP, compared to local GAAP, typically means that stricter measurement rules need to be applied, more disclosures are required and cross-country comparisons are possible. Overall, this results in more transparency and a greater detection of earnings management by investors (e.g., Hirst and Hopkins 1998).
} 
Finally, there has been some research on the specific choice between IFRS and US GAAP. In their study on voluntary adoption of a non-local GAAP, both Ashbaugh (2001) and Cuijpers et al. (2002) for example have looked at the IFRS/US GAAP dilemma, addressing the same variables as in their local versus non-local GAAP comparison. Overall they find that firms are more likely to report IFRS financial information when they are relatively larger and when they participate in seasoned equity offerings. Moreover, this likelihood increases when US-GAAP (compared to IFRS) requires more accounting policy changes relative to what is required under firms' domestic GAAPs, illustrating the impact of the home country on that choice. By contrast, being listed on a US exchange and having their shares traded on an increasing number of foreign equity markets is more often associated with firms reporting under US GAAP.

Next to firms voluntarily choosing to report either under IFRS or US GAAP, there are also firms that are obliged to make that choice. In his study, Leuz (2003b) addresses these firms, and surprisingly finds that only larger financing needs are associated with US GAAP compliance. Firm size and firm performance seem to have no significant impact on the standard choice.

Overall, these studies suggest that a firm's choice is determined by the net-benefits of that choice, or that the benefits from applying one set of standards outweigh the costs. Benefits are mainly defined in terms of (minimization of) the cost of capital, while the costs typically involve direct costs such as training, education, etc2.

\section{HYPOTHESES}

In the present study, we further explore the IFRS/US GAAP choice and differences in characteristics of companies choosing a particular standard set. According to a recent KPMG survey (KPMG 2000), choosing a new set of standards is a strategic decision that typically occurs as firms want to raise new capital. In making a choice between different GAAPs, various factors, such as the preferences of investors and analysts, are being considered by management. Also more pragmatic issues such as the implementation costs

\footnotetext{
${ }^{2}$ In most studies, these costs are either considered to be trivial, hard-to-measure or as one-time-off costs. In each case, no real attempt is made to measure these costs.
} 
and internal reporting impact influence their decision. According to the respondents of that same survey, individual differences between IFRS and US GAAP have however no considerable influence on deciding which GAAP to adopt (KPMG 2000). However, Ashbaugh (2001) finds that differences in disclosure requirements and measurement methods between domestic standards and IFRS/US GAAP do have an impact on that choice. More specifically, she concludes that when US GAAP, compared to IFRS ${ }^{3}$, requires more accounting policy changes relative to what is required under firms' domestic GAAP, firms are more likely to report IFRS information.

Building on Ashbaugh's findings, we further test the importance of accounting differences. In particular, we argue that when differences between IFRS and US GAAP are relevant to the firm, management will eventually opt for the set with the least disclosure requirements and the most measurement choices 4.

Firstly, the item on which IFRS and US GAAP differ needs to be relevant to the firm. If firms rarely engage in transactions giving rise to that item, differences between standard sets on this item might not be a significant determinant of GAAP choice. The fact that the differences need to be relevant to the firm (in order to have an impact on the regime choice) is confirmed by the KPMG study. They find that, although overall the differences do not seem to have an impact, some firms, when presented with some individual differences, do judge that difference to be important. Among the more significant issues they quote: amorisation of goodwill, pooling of interest and employee equity compensation. This suggests that individual company's circumstances need to be taking into consideration when investigating the impact of accounting differences on the choice of the standards set.

Secondly, given that the accounting item is relevant to the firm, we propose that management prefers those accounting standards with minimum disclosure requirements. We argue that managers will try to limit mandatory disclosures and maintain as much discretion as possible in reporting voluntarily to the public (see also Fishman and Hagerty (1990)). This way, they don't commit to more disclosures beforehand: they can make the

\footnotetext{
3 To illustrate this effect, Ashbaugh uses a grid, marking whether or not local GAAP has similar requirements as IFRS (US GAAP respectively) with regard to a selected number of disclosure items and measurement choices. By aggregating these scores, she develops a measure for the degree of convergence between a country's domestic GAAP and IFRS (US GAAP).

${ }^{4}$ Likewise, lobbying activities of managers at the FASB standard setting process demonstrate that management typically object to more transparent and restrictive GAAP reforms at the FASB standards setting (e.g., Hunton et al. 2004).
} 
final decision to disclose or withhold information after they have observed the underlying events, when they know more about related costs and/or the probability of certain outcomes. Managers who wish so can still reveal more than the applicable standards require5.

Next, we also posit that managers choose the standards where they have more options to measure a particular item or transition. As documented in Asbaugh and Pincus (2001), more volatile earnings are associated with greater analyst forecast errors and a negative market reaction (see also Brown (1983) and Elliott and Philbrick (1990)). Having more ways available to measure an item or transaction offers the opportunity to disguise income volatility, influence contractual outcomes (e.g., management compensation plans) and/or manage earnings. The choice to capitalize certain items, for example, offers the possibility to smoothly spread the effect of large investments. This idea is in line with a prior study by Leuz et al. (2003) and Meuwissen et al. (2004) where systematic differences in earnings management across countries (and thus across local GAAP's) are observed. In sum, these considerations result in the following hypothesis:

GENERAL HYPOTHESIS: Firms opt for the set that either allows greater flexibility in measurement choices or requires fewer disclosures on relevant accounting topics.

Note that we measure the relevance of the item on which IFRS and US GAAP differ, and not what the impact on accounting numbers would be under the two sets. The reason why we apply this approach is twofold. First, it is not always possible to measure the impact on shareholder equity and company earnings of having other and more measurement choices available. Additional and private information is often needed to complete a certain accounting treatment. Moreover, even when the difference can be calculated in one year (i.e., the year of the initial measurement), it is not clear if and how the mean reverting trend of accrual accounting should be taken into consideration. Second, the approach taken in this study allows us to include both differences in measurement

\footnotetext{
${ }^{5}$ From the disclosure literature, we know that managers opt for more disclosures when the benefits from increased disclosure (i.e. avoiding investors' rational value discounting) are considerable (e.g., Verrecchia 1983 and 2001). However, according to a study by Leuz (2003), the capital market does not react differently to IFRS versus US GAAP application. Therefore, there is no real benefit to choosing the most demanding accounting regime.
} 
choices and differences in disclosure requirements, whereas the other approach clearly only considers the first one.

In testing the general hypothesis, we focus on new economy firms, listed on the former6 German New Market (see 3.4). We select three accounting areas that are of particular interest to new economy firms. Typically, new economy firms are intensively investing in research and development activities (Ittner et al. 2003). Secondly, these firms frequently engage in mergers and acquisitions, as it enables them to quickly expand into new products and new geographic markets. And thirdly, the importance of stock options and other stock-based payments is considerable (Anderson et al. 2000, Murphy 2003). For these items, accounting differences between IFRS and US GAAP occur. Following the FASB in its comparison project (Bloomer 1999), these differences can be categorized as differences in the number of measurement choices ( $R \& D$, acquisitions) or differences in required disclosures (stock option plans)7 (Ernst\&Young 2002).

\subsection{DifFERENCES IN THE NUMBER OF MEASUREMENT CHOICES}

With respect to the R\&D expenditures and according to IFRS, firms are required to capitalize development costs (provided certain criteria are met), while research costs need to be expensed immediately (IAS 38). Under US GAAP, both research and development costs need to be expensed in the year they are incurred (FASB Statement 2, see Appendix 1). In other words, IFRS permits more discretion with regard to the $R \& D$ expenditures, which can be used for earnings management purposes or to provide information to the different stakeholders. By consequence, we hypothesize that it is more likely for firms with large $R \& D$ expenditures to choose IFRS, since the accounting treatment of R\&D is more flexible. This leads to the following hypothesis:

\footnotetext{
${ }^{6}$ The German New Market, or the high-tech and innovative market segment of the Deutsche Börse, was closed down on 5th of June 2002. All former companies from the Neuer Markt segment were migrated into either the Prime Standard or the General Standard.

${ }^{7}$ The related paragraphs of both IFRS and US GAAP regulation are included in Appendix 1.
} 
HYPOTHESIS $_{\mathrm{a}}$ : Since the accounting treatment of R\&D expenditures is more flexible and offers more alternatives under IFRS, firms with large R\&D expenditures are more likely to choose IFRS.

Another area where IFRS and US GAAP differ in the number of measurement choices they offer is the area of business combinations (IAS 22 versus APB Opinion No.16 and No. 17). Two major differences between IFRS and US GAAP with regard to those business combinations exist8. First, the conditions necessary to use the pooling-ofinterest method, as an alternative to the purchase method, are stricter under IFRS. Second, the goodwill that arises from applying the purchase method can only be amortized over a period not exceeding 20 years, compared to 40 years under US GAAP. Without pooling, acquiring other new economy companies means incurring goodwill amounts, resulting in reductions of earnings through the amortization of this goodwill. Since the amortization period is shorter under IFRS, earnings would be affected more heavily, but during a shorter period. Consequently, our hypothesis states that:

HYPOTHESIS $_{\mathrm{b}}$ : Since the accounting treatment of business combinations is less stringent under US GAAP, firms engaging in mergers and acquisitions are more likely to choose US GAAP.

\subsection{DIFFERENCES IN THE REQUIRED DISCLOSURES}

Next to differences in measurement choices, there are also differences in (the level of detail in) the disclosures that are required by IFRS and US GAAP. One such difference is with regard to the employee share option plans (Bloomer 1999). IFRS does not require nor encourage firms to reflect costs and liabilities in the financial statements (IAS 19). By

\footnotetext{
${ }^{8}$ In 2001, the FASB made two considerable changes to the accounting treatment of business combinations. First, all business combinations initiated after June 2001 have to be accounted for using the purchase method. Second, the goodwill that arises from these combinations can no longer be amortized but has to be tested annually for impairment. Effective June 2001, FAS 141 and 142 thereby supersede APB Opinion 16 and 17 respectively. Likewise, the IASB published an Exposure Draft on 5 December 2002, proposing to eliminate both the pooling method and the goodwill amortization (as eventually approved in IFRS 3 in 2004).
} 
contrast, US accounting standards do require recognition: at year end, the difference between the fair value and option exercise price must be recognized as an expense, and the related balance sheet item must be marked on the liability side (FASB Statement No. 123). In addition, US GAAP also requires more extensive disclosures. Firms applying US GAAP are, for example, required to disclose both the method and significant assumptions used to estimate the fair value of options, whereas IFRS has no similar requirements. This leads to the following hypothesis:

HYPOTHESIS: Since the accounting treatment of employee share option plans is less demanding under IFRS, firms that award option plans to their employees are more likely to choose IFRS.

In the next section, we specify the model that is used to test these hypotheses.

\section{MODEL SPECIFICATION}

The factors hypothesized as being associated with a firms' decision to report according to IFRS or US GAAP are tested using the following logit regression:

$$
\begin{aligned}
& \text { P(US/IFRS })_{i}=\alpha_{0}+\alpha_{1} \text { RD }_{\mathrm{i}}+\alpha_{2} \text { ACQ }_{\mathrm{i}}+\alpha_{3} \text { EMPRIOR }_{\mathrm{i}}+\alpha_{4} \text { SALES }_{\mathrm{i}}+\alpha_{5} \text { FLOAT }_{\mathrm{i}}+\alpha_{6} \\
& \text { FOREIGN }_{\mathrm{i}}+\alpha_{7} \text { INCSTOCK }_{\mathrm{i}}+\alpha_{8} \text { DEBT }_{\mathrm{i}}+\alpha_{9} \text { PERF }_{\mathrm{i}}+\alpha_{10} \text { INDUSTRY }_{\mathrm{i}}+\varepsilon_{\mathrm{t}}
\end{aligned}
$$

The dependent variable P(US/IFRS) equals 1 if firm i reports US GAAP financial statements and zero if a firm reports IFRS financial statements. All variables (unless otherwise mentioned) are measured in the year of the switch, as this is most appropriate for our research question. Measuring firm characteristics in one particular calendar year for all firms could imply that some firms have switched to IFRS/USGAAP years before, and that company characteristics have changed in the meantime. Therefore, the year of the switch more accurately reflects the firm characteristics that actually lead to IFRS or US GAAP preference.

The three independent variables that are introduced in the model to test the earlier developed hypotheses are RD, ACQ and EMPRIOR. The first variable, RD, proxies for the annual R\&D expenditures of a company (Hypothesis $\mathrm{s}_{\mathrm{a}}$ ). The exact annual R\&D budget cannot be used since firms do not always explicitly mention this amount as a separate line 
item in their reports. Our proxy is defined as the $R \& D$ expenses that appear on the $P \& L$ accounts in year $t$, plus the newly recorded intangibles during year $t$ minus the new goodwill during that year ${ }^{9}$. To control for size effects, we furthermore scale by total sales during year $\mathrm{t}^{10}$. As stated in HYPOTHESIS $\mathrm{s}_{\mathrm{a}}$, we expect a negative relation between the R\&D variable and US GAAP application. With the second variable, ACQ, we measure a firms' engagement in business combinations (HYPOTHESIS $\mathrm{b}$ ). This variable equals one if the company has executed an acquisition during year $t$ and 0 otherwise. An acquisition is judged to have occurred when either a new acquisition is explicitly mentioned in the notes of the annual report or when new goodwill is reported. The latter is mentioned as a separate line item in the 'change in fixed assets' table in the notes to the financial statements. The expected sign on this variable is positive. The last test variable is EMPRIOR. This variable reflects whether or not the company gives priority to its employees when issuing new equity. Information on this variable is collected from the firms' prospect at the time of the IPO. According to HYPOTHESIS $c$, the existence of employee share option plans $($ EMPRIOR=1) would be negatively associated with US GAAP adoption.

Next to the three test variables, we include a number of control variables identified by previous research as influencing the decision to disclose IFRS versus US GAAP information. The first five control variables capture investor structure and the demand for external information. The first variable is SALES or the natural logarithm of total sales in year $\mathrm{t}$ : the larger the firm, the higher the incentive to add credibility to the financial statements. Given that US GAAP overall requires more extensive disclosures and restricts manager's discretion more, this results in a positive association between SALES and the dependent variable ${ }^{11}$. A second variable is FLOAT, being the free float of the firm's shares or the percentage of shares that are not held by known shareholders. Similar as for the SALES variable, we expect that the larger this percentage, the more dispersed the

\footnotetext{
${ }^{9}$ Although new intangibles other than goodwill still contain more than only capitalised development costs, we believe that the measure can be applied in this context. If, hypothetically speaking, intangibles other than capitalised development costs would take up a large part of our measure, than still a higher value of the measure is expected to be associated with a higher likelihood of applying IFRS. Reason is that revaluations of intangible assets are allowed under IFRS (while US GAAP does not offer this opportunity) resulting in more management judgment opportunities.

${ }^{10}$ Previous studies have typically used total assets as a measure of size. However, since total assets are defined differently under IFRS and US GAAP, total assets would bias the R\&D expenditures proxy.

${ }^{11}$ Similar to previous studies, we assume that managers are led by investors' preference for overall more transparent (i.e., more rigorously defined) standards. However, investors might also prefer US standards simply because they are more familiar with those standards, compared to the rather new international standards.
} 
ownership, the higher the demand for US GAAP will $\mathrm{be}^{12}$. The third variable, FOREIGN, also looks at the current shareholders, but more at their geographical dispersion. The higher the number of (Non-US) foreign equity markets on which a firm is listed, the more widespread the current shareholders, the higher the demand for US GAAP information. Next, there is INCSTOCK variable. This variable reflects the future change in shareholders' demand for information. The variable equals one if a firm's common stock is increased by $100 \%$ in the upcoming year and zero otherwise ${ }^{13}$. Since such a change can substantially increase the number of shareholders, the demand for information also raises, again resulting in a positive relation with the application of US GAAP. Finally, a fifth variable is introduced to include the effect of investors other than the shareholders and the demand for information by external creditors. This variable is labeled DEBT and defined as the long-term debt divided by common stock. Expectations with regard to this variable are ambiguous. Some argue that many of the debt holders are 'insiders' to the firm, as they rely on private rather than public information to make decisions. By consequence, the demand for more transparent financial reporting would be lower with higher leverage, resulting in a lower association with US GAAP. There are, however, others who argue (and find) that debt holders, by closely monitoring the firm, encourage managers to make decisions that are more aligned with the interests of stockholders (e.g., Maloney et al. $1993)^{14}$. Here, more leverage would suggest US GAAP adoption. Given these different lines of reasoning, we do not predict the direction of the DEBT variable ${ }^{15}$.

\footnotetext{
${ }^{12}$ We acknowledge that there exist different types of shareholders and that composition/diversity of shareholders is important in creating incentives for management. For example, the presence of large institutional investors or block holders suggests more active monitoring on their behalf (Pound 1988, Shleifer and Vishney 1986), thereby limiting managerial discretion on accounting issues (Koh 2003, Kooyul and Soo 2002). Other examples are government involvement (Wong et al 2004) and management ownership (Ang et al. 2000, Kooyul and Soo 2002). However, since we lack detailed information on shareholder structure, we limit the analysis to the percentage of known shareholders (FLOAT).

${ }^{13}$ Most prior studies have used a dummy to reflect whether there was an increase in investor interests or not. However, given the nature of our sample firms (i.e. high growth), almost all firms would classify as increasing-capital firms (even with relatively small changes in shareholders' equity).

${ }^{14}$ Debtholders do not necessarily monitor whether management acts in the best interest of shareholders. Rather, it is there presence and expertise that leads to managers acting in the best interest of stockholders, as suggested by both theoretical (e.g., Jensen 1986) and empirical studies (e.g., Maloney et al. 1993). Moreover, especially in Germany, banks often act as trustees in directing the investments of a large proportion of individual shareholders. Bank representatives are then often included in supervisory boards (Joos and Lang 1994).

${ }^{15}$ Just as with the FLOAT variable, we realize that the diversity might be important: public versus private debt, the terms of the debt, the length of the relationship... They all determine the degree to which debt holders are stimulated to monitor management decisions or collect other-than financial statement data (e.g., Ang et al. 2000; Maloney and Mitchell 1993). However, since there are no better publicly available variables that measure these aspects, we use the leverage ratio.
} 
Finally, two additional variables are included. First, we introduce the variable PERF, defined as a firm's sales margin. Based on findings in the disclosure literature, the better performing firms are prepared to disclose more, resulting in a higher likelihood of applying US GAAP. With our last control variable, INDUSTRY, we control for industry effects, acknowledging that firms' standard choice might be influenced by the behavior of other companies in the same industry. Since most of the world's leading companies in the non-traditional sectors are US-based and given that comparability between firms in the same sector is desirable, firms in the non-traditional sectors are more likely to apply US standards. As non-traditional sectors we consider the telecom sector, IT, software, internet, medical technology and biotech while industry and manufacturing are more traditional sectors.

Unlike prior studies, we did not include any country level variables (e.g. degree of convergence between local and international GAAP). Reason is that $88 \%$ of our sample is Germany-based, resulting in too little variation in a country variable to run statistically sound regressions ${ }^{16}$. An overview of all these variables is given in Table 1.

TABLE 1: OVERVIEW OF CHOICE MODEL VARIABLES

\begin{tabular}{|c|c|c|}
\hline & & $\begin{array}{l}\text { Expected } \\
\text { Sign }\end{array}$ \\
\hline \multicolumn{3}{|c|}{ Dependent Variable } \\
\hline $\mathrm{P}(\mathrm{US} / \mathrm{IFRS})$ & = probability of using US GAAP (1) versus IFRS (0) & \\
\hline \multicolumn{3}{|c|}{ Explanatory Test Variabales } \\
\hline $\mathrm{RD}$ & $=\left(\right.$ expensed $R \& D_{t}+$ new intangibles ${ }_{t}-$ new goodwill $\left.{ }_{t}\right) /$ total sales $_{t}$ & - \\
\hline ACQ & $=1$ if an acquisition occurred during year $\mathrm{t}$; 0 otherwise & + \\
\hline EMPRIOR & $=1$ if employees have share priority rights at the time of IPO & - \\
\hline \multicolumn{3}{|c|}{ Explanatory Control Variables } \\
\hline SALES & $=$ natural logarithm of total sales $\mathrm{t}_{\mathrm{t}}$ & + \\
\hline FLOAT & $=100-$ percentage of shares held by known shareholders at time of IPO & + \\
\hline FOREIGN & $=1$ if the firm is cross-listed on a foreign equity market; 0 otherwise & + \\
\hline INCSTOCK & $=1$ if common stock doubles between year $\mathrm{t}$ and year $\mathrm{t}+1$ & + \\
\hline DEBT & $=$ total long-term debt $_{\mathrm{t}} /$ common equit $_{\mathrm{t}}$ & $?$ \\
\hline PERF & $=$ net operating profit $_{\mathrm{t}} /$ total sales $_{\mathrm{t}}$ & + \\
\hline INDUSTRY & $\begin{array}{l}=1 \text { if activities are either telecom, IT, software, internet, medical technology } \\
\text { or biotech; } 0 \text { otherwise }\end{array}$ & + \\
\hline
\end{tabular}

\footnotetext{
${ }^{16}$ Untabulated multivariate results where we make a distinction between (1) German and non-German companies and (2) between code and common law countries, show that there is no significant influence of country on the standard set choice. For the common/code law model, the maximum likelihood estimate doesn't exist.
} 


\section{SAMPLE SELECTION AND DATA COLLECTION}

To test the hypotheses, we compose a sample of companies listed on the German New Market (see Table 2). Listing requirements on this market demand firms to either follow IFRS or US GAAP. Since the application of local standards is not allowed, our results on the IFRS/ US GAAP choice determinants are not distorted by selection bias.

In selecting the sample companies, we rely on IPO information provided on the New Market website. We first select all firms that are first time listed on this market either in 1997, 1998 or 1999. We limit ourselves to this period, since relatively few amendments or changes are made to either set of standards during the period 1997-2000 ${ }^{17}$. Then, we collect data on these firms using two sources: (1) the Worldscope database for obtaining financial data and (2) hardcopy versions of the firm's prospect ${ }^{18}$ and annual reports, to complement the financial data with more qualitative or descriptive data. Of the 183 IPO's, there are 27 companies for which there are no data available whatsoever and 12 firms for which we aren't able to obtain a hardcopy annual report. Due to incomplete financial data, we further delete 7 firms and additionally, we exclude two companies from our sample because they are active in the financial sector.

For the remaining 135 companies, we scan the hardcopy annual reports in the years surrounding the IPO to determine both the actual set of international standards and the first year of application. Firms are classified as IFRS (US GAAP) firms if they declare their statements in conformity with IFRS (US GAAP) in the summary of accounting policies in their notes and/or if the auditor states in his report that the accounts are IFRS (US GAAP) compliant. We determine the year of the switch since this will be the basis for collecting and comparing firms' accounting and financial data.

From the 135 firms, 14 companies are deleted because we are unclear about the accounting standards being used. Ten other companies continue to report under local GAAP, be it with a reconciliation or transition (of both net income and shareholders' equity) to an international set. To avoid a mix up of both locally and non-locally stated data, we delete these 10 firms. Finally, we also exclude 3 companies that are cross-listed

\footnotetext{
${ }^{17}$ The IASB initiated an improvements project in that period. However, the standards that were newly issued or changed because of the project only became effective on the $1^{\text {st }}$ of January 2001, meaning that they should be applied to annual periods beginning on or after $1^{\text {st }}$ of January 2001.

${ }^{18}$ Two variables (being EMPRIOR and FLOAT) are measured using prospect information. Reason is that financial statements might provide incomplete or biased representation of the respective item.
} 
on Nasdaq or New York Stock Exchange because of the specific characteristics of locally reported accounting information of U.S. cross-listed firms (Lang et al. 2003). In the end, the final sample consists of 108 companies ${ }^{19}$.

TABLE 2: SAMPLE SELECTION PROCEDURE (STUDY 2)

183 IPO's by the end of 1999

$\begin{array}{rrl} & \text { REASON FOR DELETION } \\ - & 27 & \text { no Worldscope data and no hardcopy of annual report } \\ - & 12 & \text { no hardcopy of the annual report } \\ - & 7 & \text { incomplete financial data } \\ - & 2 & \text { companies active in the financial sector } \\ - & 14 & \text { unknown date of first-time IFRS/US GAAP application } \\ - & 10 & \text { applying local GAAP } \\ - & 3 & \text { NASDAQ / NYSE cross-listed companies }\end{array}$

108 sample companies

\section{RESULTS}

\subsection{DESCRIPTIVE STATISTICS AND UNIVARIATE RESULTS}

The results show that $41 \%$ or 44 sample firms apply US GAAP while 64 companies choose to adopt IFRS. For a large majority of firms, the year of the switch coincides with the year of IPO. Notwithstanding the market requirements to apply IFRS or US GAAP from the IPO onwards, some firms seem to delay their first time application of non-local standards with one or two years (see Table 3). The length of that delay is moreover not significantly different for IFRS and US GAAP (Wilcoxon p-value of 0.37 ).

\footnotetext{
${ }^{19}$ Following the new segmentation of the Deutsche Börse, these sample firms were listed on either the Prime or the General Standard starting June 2003. Based on March 2004 data, we conclude that 69 went onto the Prime Standard, while 36 remained on the General Standard. The six other sample firms either went bankrupt or merged in the meantime.
} 


\begin{tabular}{ccccc}
\hline & \multicolumn{5}{c}{ First-time application of IFRS or US GAAP } \\
\cline { 2 - 5 } Year of the IPO & 1997 & 1998 & 1999 & 2000 \\
\hline 1997 & 2 & 1 & 2 & - \\
1998 & - & 19 & 9 & - \\
1999 & - & 7 & 53 & 15 \\
\hline
\end{tabular}

Firms are on average 13 years old when they make the switch from local GAAP to IFRS or US GAAP. Almost half of the sample firms are even younger then 10 years at the time of the switch, while only 5 firms are more than 30 years old. As can be expected, given the geographical location of the market, the vast majority of our sample firms $(88 \%)$ are incorporated in Germany. The remaining firms are either from Austria (7), Israel (3), the Netherlands (2) or Switzerland (1). Next to being listed on the German New Market, there are some firms that are cross-listed on other markets. These markets are Nasdaq Europe, Buda Stock Exchange or the U.S. over-the-counter Market ${ }^{20}$. The activities in which the sample firms operate range from internet, software and IT over medtech, biotech and telecom to technology, media and industry (see Table 4).

TABLE 4: SAMPLE COMPOSITION WITH REGARD TO COMPANY ACTIVITIES

\begin{tabular}{lcc}
\hline & Absolute & Percentage \\
\hline Industry and Manufacturing & 7 & $6.48 \%$ \\
Technology & 23 & $21.30 \%$ \\
Media & 14 & $12.96 \%$ \\
Biotech & 5 & $4.63 \%$ \\
Medical Technology & 3 & $2.78 \%$ \\
Internet & 15 & $13.89 \%$ \\
Information Technology & 17 & $15.74 \%$ \\
Software & 18 & $16.67 \%$ \\
Telecom & 6 & $5.56 \%$ \\
\cline { 2 - 3 } & 108 & $100.00 \%$ \\
\hline
\end{tabular}

\footnotetext{
${ }^{20}$ OTC firms trade in the U.S., but face a different regulatory environment (Lang et al. 2003). In particular, OTC firms do not need to edit reconciliations to U.S. GAAP and they also do not face increased enforcement by the Securities and Exchange Commission.
} 
Before discussing the univariate results, we first provide a number of descriptives for the entire sample in Table 5. First, we find that the three items selected to investigate the impact of accounting differences are highly relevant to our sample firms. Two thirds of the sample firms engage in business combinations, 67\% assign employee stock options and, on average $22 \%$ of annual sales is invested in research and development activities. Second, we conclude that, although the equity market is addressed to attract (FOREIGN= 0.18 ) and increase capital (INCSTOCK MEAN $=0.19$ ), debt financing is still considerable. Twenty-five percent of the sample firms have almost as much long-term debt as common equity capital $\left(\mathrm{DEBT}_{\mathrm{Q} 3}=0.97\right)$. This is not surprising, given that $88 \%$ of our sample firms are incorporated in Germany, where firms typically rely heavily on bank financing (Joos and Lang 1994). Finally, we also observe that more than half of the companies are active in non-traditional industries (INDUSTRY $\mathrm{Q}_{2}=1$ ) and typically sell their products or services at a loss $\left(\right.$ PERF $\left._{\text {MEAN }}=-0.14\right)$.

TABLE 5: DESCRIPTIVE STATISTICS ON CHOICE MODEL VARIABLES

\begin{tabular}{lccccc}
\hline & MEAN & ST DEV & Q1 & Q2 & Q3 \\
\hline RD & 0.2164 & 0.5167 & 0.0077 & 0.0408 & 0.1305 \\
ACQ & 0.7500 & 0.4350 & 0.5 & 1 & 1 \\
EMPRIOR & 0.6667 & 0.4736 & 0 & 1 & 1 \\
PPEQ & 0.1098 & 0.1179 & 0.0227 & 0.0601 & 0.1584 \\
SALES & 10.3574 & 1.1954 & 9.5789 & 10.2406 & 11.2042 \\
FLOAT & 51.9692 & 18.9866 & 37.1250 & 49.6000 & 64.8000 \\
FOREIGN & 0.1759 & 0.3825 & 0 & 0 & 0 \\
INCSTOCK & 0.1852 & 0.3902 & 0 & 0 & 0 \\
DEBT & 7.7646 & 57.2698 & 0 & 0.0925 & 0.9711 \\
PERF & -0.1379 & 0.6807 & -0.1007 & 0.0229 & 0.1004 \\
INDUSTRY & 0.5926 & 0.4936 & 0 & 1 & 1 \\
\hline
\end{tabular}


Results from the univariate tests are presented in Table 6. Non-parametric MannWhitney tests $^{21}$ are performed on the continuous variables, while the dichotomous variables are tested using a $\chi^{2}$-test. On average, we find that IFRS firms (1) spend significantly more on research and development activities (RD, p=.07) and (2) are less frequently quoted on foreign equity markets (FOREIGN, $p=.01$ ) compared to US GAAP firms. Furthermore, we also see that relatively more IFRS firms award their employees with share priority rights (EMPRIOR, $\mathrm{p}=.07$ ) and engage in large equity offerings (INCSTOCK, p=.04) as opposed to firms applying US GAAP. Finally, the results also show a choice difference between industries (INDUSTRY, $\mathrm{p}=.05$ ) where firms that are characterized as non-traditional more frequently choose for US GAAP compared to more traditional firms. No significant differences are found between the two groups with regard to their engagement in acquisitions, size, percentage of unknown shareholders, debt structure and performance (respectively ACQ, SALES, FLOAT, DEBT, PERF).

${ }^{21}$ Non-parametric tests are performed instead of parametric t-tests since the variables are not normally distributed within the IFRS and/or US GAAP group. 


\begin{tabular}{|c|c|c|c|c|}
\hline & IFRS firms & US GAAP firms & Mann-Whitney U-test & Chi-square test \\
\hline $\mathrm{RD}$ & $\begin{aligned} \mu & =0.2371 \\
\sigma & =0.58\end{aligned}$ & $\begin{array}{l}\mu=0.1862 \\
\sigma=0.41\end{array}$ & $\begin{array}{l}Z=1.4914 \\
\left(p=0.07^{*}\right)\end{array}$ & NA \\
\hline ACQ & $\begin{array}{l}\mu=0.7031 \\
\sigma=0.46\end{array}$ & $\begin{array}{l}\mu=0.8182 \\
\sigma=0.40\end{array}$ & NA & $\begin{array}{c}\chi^{2}=1.8409 \\
(p=0.17)\end{array}$ \\
\hline EMPRIOR & $\begin{array}{l}\mu=0.7344 \\
\sigma=0.45\end{array}$ & $\begin{array}{l}\mu=0.5682 \\
\sigma=0.50\end{array}$ & NA & $\begin{array}{c}\chi^{2}=3.2408 \\
\left(p=0.07^{\star}\right)\end{array}$ \\
\hline SALES & $\begin{aligned} \mu & =10.4826 \\
\sigma & =1.16\end{aligned}$ & $\begin{array}{l}\mu=10.1752 \\
\sigma=1.24\end{array}$ & $\begin{array}{c}Z=-0.991 \\
(p=0.16)\end{array}$ & NA \\
\hline FLOAT & $\begin{array}{l}\mu=49.9905 \\
\sigma=16.68\end{array}$ & $\begin{array}{l}\mu=54.8473 \\
\sigma=21.80\end{array}$ & $\begin{array}{c}Z=1.0161 \\
(p=0.15)\end{array}$ & NA \\
\hline FOREIGN & $\begin{aligned} \mu & =0.1094 \\
\sigma & =0.31\end{aligned}$ & $\begin{array}{l}\mu=0.2727 \\
\sigma=0.45\end{array}$ & $\begin{array}{l}Z=2.1758 \\
\left(p=0.01^{\star \star}\right)\end{array}$ & NA \\
\hline INCSTOCK & $\begin{aligned} \mu & =0.2500 \\
\sigma & =0.44\end{aligned}$ & $\begin{array}{l}\mu=0.0909 \\
\sigma=0.29\end{array}$ & NA & $\begin{array}{l}\chi^{2}=4.3736 \\
\left(p=0.04^{\star *}\right)\end{array}$ \\
\hline DEBT & $\begin{array}{l}\mu=0.6332 \\
\sigma=1.14\end{array}$ & $\begin{aligned} \mu & =18.1375 \\
\sigma & =89.30\end{aligned}$ & $\begin{array}{c}Z=0.4461 \\
(p=0.66)\end{array}$ & NA \\
\hline PERF & $\begin{array}{l}\mu=-0.0481 \\
\sigma=0.41\end{array}$ & $\begin{array}{l}\mu=-0.2685 \\
\sigma=0.94\end{array}$ & $\begin{array}{c}Z=-0.2970 \\
(p=0.38)\end{array}$ & NA \\
\hline INDUSTRY & $\begin{aligned} \mu & =0.5156 \\
\sigma & =0.50\end{aligned}$ & $\begin{aligned} \mu & =0.7045 \\
\sigma & =0.46\end{aligned}$ & NA & $\begin{array}{l}\chi^{2}=3.8546 \\
\left(p=0.05^{\star}\right)\end{array}$ \\
\hline
\end{tabular}

NA: Not Appropriate

${ }^{*}, * *=p$-value $<.10, .05$ respectively

\subsection{MULTivariate RESULtS}

Results from applying the model specified in section 4 are shown in Table 7 (see model 1). Overall, the model is highly significant with a $\chi$-square of $35.48(\mathrm{p}<0.0001)$, a pseudo R-square of $32,10 \%$ and $80 \%$ of the observations correctly classified. Furthermore, we find evidence to support all three hypotheses. The first hypothesis, relating choice to the annual R\&D expenditures, is significant at $8 \%$-level and results in a negative coefficient: the higher the R\&D budget, the less likely that US GAAP is being applied. The fact that development costs may be capitalized under IFRS, and not according to others, indeed has an impact on the standards choice for firms with high R\&D 
expenditures. Evidence for the second hypothesis is less strong, but still significant at 10\%-level (with a p-value of 0.0911). The positive parameter on ACQ indicates that firms engaging in acquisitions are more frequently associated with US GAAP compliance than with IFRS. Since US GAAP offers the opportunity to account for acquisitions in a way where earnings are less affected in the short run, this confirms HYPOTHESIS $\mathrm{b}_{\mathrm{b}}$. Finally, also the last hypothesis with regard to employee share option plans is confirmed (EMPRIOR = 1.0048). Firms that award their employees with share option plans will more likely apply IFRS, or the standard that requires less disclosures on this item $(\mathrm{p}=0.0583)$.

With regard to the control variables, we find results consistent with previous research for foreign equity listings (FOREIGN): being listed on a Non-US, foreign equity market is associated with a higher probability of applying US GAAP (FOREIGN = 1.7912, $\mathrm{p}=0.0131$ ). Contrary to previous research, we find a negative effect of stock increases (INCSTOCK $=-2.2339, \mathrm{p}=0.0047$ ). This negative association could be due to the fact that the sample companies are European based and that raising capital mainly happens on European markets. Unlike other studies, we also find significant results for the INDUSTRY variable $(\mathrm{p}=0.0506)$. Companies that operate in the high-tech sectors, are more likely to apply US GAAP (INDUSTRY=1.0645).

In Table 7, we also present model 2, where the variables that relate to specific accounting differences are excluded. Compared to this reduced model, results from model 1 clearly indicate that specific accounting differences do have an (incremental) impact on the standard regime choice. The model's pseudo R-square increases from $20 \%$ to $32 \%$ by adding these variables (while there are no significant changes in the control variables). 
TABLE 7: MULTIVARIATE RESULTS OF THE CHOICE MODEL

$\mathrm{P}(\mathrm{US} /$ IFRS $)=\alpha_{0}+\alpha_{1}$ RD $+\alpha_{2}$ ACQ $+\alpha_{3}$ EMPRIOR $+\alpha_{4}$ SALES $+\alpha_{5}$ FLOAT $+\alpha_{6}$ FOREIGN $+\alpha_{7}$ INCSTOCK $+\alpha_{8}$ DEBT $+\alpha_{9}$ PERF $+\alpha_{10}$ INDUSTRY

\begin{tabular}{|c|c|c|c|c|c|c|c|c|}
\hline \multirow[b]{2}{*}{ Variable } & \multicolumn{4}{|c|}{ MODEL 1: BASE MODEL } & \multicolumn{4}{|c|}{ MODEL 2: REDUCED MODEL } \\
\hline & $\begin{array}{l}\text { Parameter } \\
\text { Estimate }\end{array}$ & $\begin{array}{l}\text { Standard } \\
\text { Error }\end{array}$ & $\begin{array}{l}\text { Wald Chi- } \\
\text { Square }\end{array}$ & $\mathrm{p}<($ ChiSQ $)$ & $\begin{array}{l}\text { Parameter } \\
\text { Estimate }\end{array}$ & $\begin{array}{l}\text { Standard } \\
\text { Error }\end{array}$ & $\begin{array}{l}\text { Wald Chi- } \\
\text { Square }\end{array}$ & $\mathrm{p}<($ ChiSQ $)$ \\
\hline INTERCEPT & -1.5137 & 2.7196 & 0.3098 & 0.5778 & -2.2810 & 2.5044 & 0.8295 & 0.3624 \\
\hline $\mathrm{RD}$ & -1.0774 & 0.6122 & 3.0970 & 0.0784 * & & & & \\
\hline $\mathrm{ACQ}$ & 0.9871 & 0.5842 & 2.8548 & 0.0911 * & & & & \\
\hline EMPRIOR & -1.0048 & 0.5306 & 3.5859 & 0.0583 * & & & & \\
\hline SALES & -0.0625 & 0.2318 & 0.0726 & 0.7876 & 0.0221 & 0.2150 & 0.0105 & 0.9182 \\
\hline FLOAT & 0.0203 & 0.0128 & 2.5383 & 0.1111 & 0.0179 & 0.0120 & 2.2098 & 0.1371 \\
\hline FOREIGN & 1.7912 & 0.7219 & 6.1565 & $0.0131 * \star$ & 1.0875 & 0.5940 & 3.3526 & $0.0671 * *$ \\
\hline INCSTOCK & -2.2339 & 0.7897 & 8.0012 & $0.0047 * \star$ & -1.7734 & 0.7240 & 5.9991 & $0.0143 * *$ \\
\hline PERF & -0.6233 & 0.5889 & 1.1205 & 0.2898 & -0.2631 & 0.3620 & 0.5281 & 0.4674 \\
\hline DEBT & 0.1210 & 0.1439 & 0.7077 & 0.4002 & 0.1625 & 0.1269 & 1.6396 & 0.2004 \\
\hline INDUSTRY & 1.0645 & 0.5445 & 3.8221 & 0.0506 * & 0.9551 & 0.4927 & 3.7574 & 0.0526 * \\
\hline & & Model $\chi^{2}$ & 35.48 ** & & & Model $\chi^{2}$ & $24.52 * \star$ & \\
\hline & & Pseudo-R ${ }^{2}$ & 0.32 & & & Pseudo-R ${ }^{2}$ & 0.20 & \\
\hline & & Concordant & $80.0 \%$ & & & Concordant & $74.1 \%$ & \\
\hline
\end{tabular}

The dependent variable, P(US/IFRS), equals 1 if US GAAP are applied, 0 if IFRS are applied. Independent variables are defined in Table 3.1.

${ }^{*}, * *=p$-value $<.10, .05$ respectively 
In testing the robustness of our findings, we alternatively define a number of variables. For example, we expand the acquisition window to two years since it might be argued that plans for future acquisitions are not fully captured within a one-year window. This variable is labeled $\mathrm{ACQ}_{\mathrm{LT}}$. We also replace the INCSTOCK dummy by the DSTOCK dummy, where the variable takes 1 if there is an increase in common stock and 0 if not. The debt structure is alternatively proxied by the percentage of short-term debt (with common stock as denominator; STDEBT) and the firms' industry is measured applying a more traditional industry variable (MANUFACT), distinguishing between manufacturing and service companies. Finally, we measure performance by the operational cash flow scaled by total sales (CASHFLOW).

Overall, and as documented in Appendix 2, all models (3 to 7) outperform the reduced model, model 2, where no specific accounting differences are taken into account. The percentage of firms classified correctly by these models ranges from .77 to .80 . Except for small changes in the significance levels, the evidence remains consistent with our hypotheses and the sign of the coefficients stays constant.

Note, however, that the alternative acquisitions variable $\left(\mathrm{ACQ}_{\mathrm{LT}}\right)$ results in a positive but insignificant parameter estimate $\left(\mathrm{ACQ}_{\mathrm{LT}}=0.6210, \mathrm{p}=0.3242\right)$. This might be caused by the public debate regarding the appropriateness of the pooling method (under US GAAP) that was going on during our sample period. The FASB issued an exposure draft suggesting to eliminate pooling for all business combinations in 1999 (Bloomer, 1999). The decision to eliminate the pooling method became effective only in 2001 . Since most of our sample firms switch to an international GAAP in that period (59 \% in 1999, see Table 3), it is reasonable to expect that firms anticipate this development, and, by consequence, that this difference between IFRS and US GAAP is no longer relevant. This argument is supported by the fact that the acquisition variable becomes even less significant when the two-year acquisition window is applied (going from $\mathrm{p}=0.0911$ to $\mathrm{p}=0.3242)$.

Finally, the insignificant effect we obtain on the alternative industry variable (MANUFACT $=-0.5548, \mathrm{p}=0.2920$ ) seems to suggest that a manufacturing / services distinction is irrelevant in this context, whereas the high-tech/ low-tech difference does impact standard choice. 


\subsection{EXTENSIONS}

Two questions remain unanswered in the basic model. First, is it fair to say that accounting differences influence standard choice only when the involved item or transaction is relevant or are accounting differences on irrelevant items also important? Secondly, does a firm with more than one relevant accounting difference in favor of IFRS have a greater incentive to apply IFRS than a firm with only one? And what about firms that simultaneously have an incentive to choose US GAAP, for example because they are frequently involved in acquisitions?

First, we elaborate on the relevance aspect of the selected items. In our general hypothesis we state that firms opt for the set that either allows greater flexibility in measurement choices or requires fewer disclosures on relevant accounting topics. From the descriptives in section, we already learned that the items we selected, and on which IFRS and US GAAP differ, are important to our sample firms. However, our tests in the multivariate section would be more convincing when we added a new item on which IFRS and US GAAP also differ, but which in itself might be less relevant for our sample firms and thus less decisive in choosing a standards set. Therefore, we include a variable capturing the firm's investment in property, plant and equipment. Descriptives show that, on average, this item compromises only $11 \%$ of the balance sheet total (see Table 5).

In general, both IFRS and US GAAP require items of property, plant and equipment to be carried at its cost less any accumulated depreciation and any accumulated impairment losses. But besides this benchmark treatment, IFRS also allows firms to measure the item at a revalued amount, being its fair value at the date of the revaluation less any subsequent depreciation and amortizations. Since IFRS offers more discretion to management and revaluations improve the balance sheet (by increasing the firms' equity base), we would expect firms with a lot of tangible assets to choose for IFRS. The variable is measured as the gross amount (i.e., irrespective of the subsequent measurement) of property plant and equipment in the year of the switch, scaled by total sales in that year (PPEQ). The following model is estimated:

$$
\begin{aligned}
& \text { P(US/IFRS })=\alpha_{0}+\alpha_{1} \text { RD }+\alpha_{2} \text { ACQ }+\alpha_{3} \text { EMPRIOR }+\alpha_{4} \text { PPEQ }+\alpha_{5} \text { SALES }+\alpha_{6} \text { FLOAT } \\
& +\alpha_{7} \text { FOREIGN }+\alpha_{8} \text { INCSTOCK }+\alpha_{9} \text { DEBT }+\alpha_{10} \text { PERF }+\alpha_{11} \text { INDUSTRY }
\end{aligned}
$$


The results from rerunning model 1 with the additional test variable PPEQ are presented in Table 8. No significant changes are made to the model, as the number of observations classified correctly by this model is similar as in model 1 (Concordant $=80 \%$ ) and our three test variables remain significant $(p=0.0715, p=0.0979$ and $p=0.0673$ respectively). The coefficient of PPEQ is however insignificant $(\mathrm{p}=0.35)$, suggesting that this item does not have a decisive influence on the IFRS/US GAAP choice.

TABLE 8: MULTIVARIATE RESULTS OF THE CHOICE MODEL, INCLUDING A PROPERTY, PLANT AND EQUIPMENT VARIABLE

\begin{tabular}{|c|c|c|c|c|}
\hline \multicolumn{5}{|c|}{$\begin{array}{c}\mathrm{P}(\mathrm{US} / \mathrm{IFRS})=\alpha_{0}+\alpha_{1} \mathrm{RD}+\alpha_{2} \text { ACQ }+\alpha_{3} \text { EMPRIOR }+\alpha 4 \text { PPEQ }+\alpha_{5} \text { SALES }+\alpha_{6} \text { FLOAT } \\
+\alpha_{7} \text { FOREIGN }+\alpha_{8} \text { INCSTOCK }+\alpha_{9} \text { DEBT }+\alpha_{10} \text { PERF }+\alpha_{11} \text { INDUSTRY }\end{array}$} \\
\hline Variable & $\begin{array}{l}\text { Parameter } \\
\text { Estimate }\end{array}$ & $\begin{array}{l}\text { Standard } \\
\text { Error }\end{array}$ & $\begin{array}{l}\text { Wald Chi- } \\
\text { Square }\end{array}$ & $\begin{array}{c}\mathrm{p}< \\
\text { (ChiSQ) }\end{array}$ \\
\hline INTERCEPT & -1.5033 & 2.7848 & 0.2914 & 0.5893 \\
\hline $\mathrm{RD}$ & -1.2035 & 0.6678 & 3.2484 & 0.0715 * \\
\hline ACQ & 0.9736 & 0.5882 & 2.7392 & 0.0979 * \\
\hline EMPRIOR & -1.0057 & 0.5497 & 3.3474 & 0.0673 * \\
\hline PPEQ & 0.5816 & 0.6257 & 0.8640 & 0.3526 \\
\hline SALES & -0.0742 & 0.2355 & 0.0993 & 0.7527 \\
\hline FLOAT & 0.0213 & 0.0134 & 2.5468 & 0.1105 \\
\hline FOREIGN & 1.6744 & 0.7355 & 5.1834 & 0.0228 ** \\
\hline INCSTOCK & -2.2126 & 0.7852 & 7.9400 & 0.0048 ** \\
\hline PERF & -0.5284 & 0.6068 & 0.7583 & 0.3839 \\
\hline DEBT & 0.0863 & 0.1211 & 0.5080 & 0.4760 \\
\hline \multirow[t]{4}{*}{ INDUSTRY } & 1.0833 & 0.5537 & 3.8277 & 0.0504 * \\
\hline & & Model $\chi^{2}$ & 33.44 * & \\
\hline & & Pseudo- $R^{2}$ & 0.32 & \\
\hline & & Concordant & $79.8 \%$ & \\
\hline
\end{tabular}

The dependent variable, P(US/IFRS), equals 1 if US GAAP are applied, 0 if IFRS are applied. Independent variables are defined in Table 1.

${ }^{*}, * *=p$-value $<.10, .05$ respectively 
To answer the second question, we reformulate he basic model. The previous model was specified as a linear, additive model, thereby assuming that the effect of for example engaging in acquisitions is constant over the whole range of the $R \& D$ intensity. It might however be reasonable to expect that there is a cumulative and/or trade-off effect between these variables. A firm that invests in R\&D and rewards its employees with share options can be expected to have a larger incentive to apply IFRS than a firm that only engages in $R \& D$ activities. In accommodating for any interaction effects, we first redefine the ACQ-test variables so that higher values of this variable are expected to be associated with IFRS GAAP adoption (as is the case for the other test variables). Following, we run a full rank interactive model:

$$
\begin{aligned}
& \text { P(US/IFRS })=\alpha_{0}+\alpha_{1} \text { RD }+\alpha_{2} \text { RACQ }+\alpha_{3} \text { EMPRIOR }+\alpha_{4} \text { RD*RACQ }+\alpha_{5} \\
& \text { RD*EMPRIOR }+\alpha_{6} \text { RACQ*EMPRIOR }+\alpha_{7} \text { RD*RACQ*EMPRIOR }+\alpha_{8} \text { SALES }+\alpha_{9} \\
& \text { FLOAT }+\alpha_{10} \text { FOREIGN }+\alpha_{11} \text { INCSTOCK }+\alpha_{12} \text { DEBT }+\alpha_{13} \text { PERF }+\alpha_{14} \text { INDUSTRY }
\end{aligned}
$$

With RACQ equaling 1 when the firm is not engaged in mergers and acquisitions ( 0 otherwise). All other variables are as defined in Table 1.

As the results in Table 9 show, we find no direct evidence of any interactive effects $^{22}$. Looking at the degree of correlation between the three variables (see Appendix 3), firms are typically confronted with only one of the items at a time, eliminating any opposing or mutually reinforcing incentives.

\footnotetext{
${ }^{22}$ Alternatively, we also performed a median split on the RD variable (median $=0.0408$, see Table 2.5 ). The model is however not reported since it suffers from quasi-complete separation of data-points.
} 
TABLE 9: MULTIVARIATE RESULTS OF THE INTERACTIVE CHOICE MODEL

\begin{tabular}{|c|c|c|c|c|}
\hline \multicolumn{5}{|c|}{$\begin{array}{c}\text { P(US/IFRS })=\alpha_{0}+\alpha_{1} \text { RD }+\alpha_{2} \text { RACQ }+\alpha_{3} \text { EMPRIOR }+\alpha_{4} \text { RD*ACQ }+\alpha_{5} \text { RD*EMPRIOR } \\
+\alpha_{6} \text { ACQ } * \text { EMPRIOR }+\alpha_{7} \text { RD*ACQ*EMPRIOR }+\alpha_{8} \text { SALES }+\alpha_{9} \text { FLOAT }+\alpha_{10} \\
\text { FOREIGN }+\alpha_{11} \text { INCSTOCK }+\alpha_{12} \text { DEBT }+\alpha_{13} \text { PERF }+\alpha_{14} \text { INDUSTRY }\end{array}$} \\
\hline Variable & $\begin{array}{l}\text { Parameter } \\
\text { Estimate }\end{array}$ & $\begin{array}{l}\text { Standard } \\
\text { Error }\end{array}$ & $\begin{array}{l}\text { Wald Chi- } \\
\text { Square }\end{array}$ & $\mathrm{p}<$ \\
\hline INTERCEPT & -0.7073 & 2.7577 & 0.0658 & 0.7976 \\
\hline $\mathrm{RD}$ & -2.7723 & 1.8988 & 2.1317 & 0.1443 \\
\hline RACQ & -2.0626 & 1.2999 & 2.5178 & 0.1126 \\
\hline EMPRIOR & -1.4051 & 0.6991 & 4.0399 & $0.0444 * *$ \\
\hline RD*RACQ & 25.7678 & 51.5140 & 0.2502 & 0.6169 \\
\hline RD*EMPRIOR & 1.6348 & 2.2190 & 0.5427 & 0.4613 \\
\hline RACQ*EMPRIOR & 0.9592 & 1.5388 & 0.3886 & 0.5331 \\
\hline RD*RACQ*EMPRIOR & -24.9457 & 51.4713 & 0.2349 & 0.6279 \\
\hline SALES & -0.0096 & 0.2396 & 0.0016 & 0.9681 \\
\hline FLOAT & 0.0205 & 0.0131 & 2.4580 & 0.1169 \\
\hline FOREIGN & 1.6232 & 0.7708 & 4.4344 & 0.0352 ** \\
\hline INCSTOCK & -2.2381 & 0.8002 & 7.8219 & 0.0052 ** \\
\hline PERF & -0.5858 & 0.6001 & 0.9531 & 0.3289 \\
\hline DEBT & 0.1430 & 0.1574 & 0.8260 & 0.3634 \\
\hline \multirow[t]{4}{*}{ INDUSTRY } & 1.0695 & 0.5686 & 3.5380 & 0.0600 * \\
\hline & & Model $\chi^{2}$ & \multicolumn{2}{|c|}{$38.99 * *$} \\
\hline & & Pseudo-R ${ }^{2}$ & \multicolumn{2}{|c|}{0.36} \\
\hline & & Concordant & \multicolumn{2}{|c|}{$81.4 \%$} \\
\hline
\end{tabular}

The dependent variable, $P($ US/IFRS), equals 1 if US GAAP are applied, 0 if IFRS are applied. Independent variables are defined in Table 2.1.

${ }^{*},{ }^{* *}=\mathrm{p}$-value $<.10, .05$ respectively

\section{FLEXIBILITY: FOR BETTER OR FOR WORSE?}

One of the major conclusions from the previous section is that firms choose the standard set that offers them the most flexibility on relevant accounting issues.

Nonetheless, an important question remains, namely how is earnings affected by offering firms this flexibility. For example, does the flexibility make the reported earnings number more value relevant? In order to examine the impact on earnings, we study two earnings attributes: predictability and value relevance. In particular, we investigate whether 
flexibility in financial statement reporting results in (a) users better predicting future cash flows and (b) information that better reflects underlying firm value.

While the valuation question can be investigated for all three accounting items discussed in section 3, the question on predictability cannot. Reason is that the link with future performance is not clear for all three accounting items: only a direct link between the R\&D and future performance has been documented to exist (Aboody and Lev, 1999). For goodwill and employee benefit disclosures, this link is far less obvious. Both questions will therefore be examined by addressing only the $R \& D$ recognition. More specifically, our two questions are: (a) does the practiced R\&D capitalization provide any additional information about future performance and (b) does the capitalized R\&D amount contain value relevant information? Since flexibility on this item is only offered under IFRS (whereas US GAAP requires immediate expensing), and we are interested in the effective use of that flexibility, we consider only the IFRS subsample in this section.

TABLE 10: DESCRIPTIVE STATISTICS ON R\&D TREATMENT

\begin{tabular}{|c|c|c|c|}
\hline \multicolumn{4}{|l|}{ Panel A: Total Sample Descriptives } \\
\hline & $\begin{array}{l}\text { IFRS } \\
\text { sample }\end{array}$ & $\begin{array}{l}\text { US GAAP } \\
\text { sample }\end{array}$ & $p<$ \\
\hline 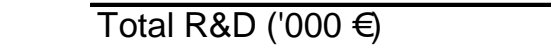 & 156,529 & 4,759 & 0.95 \\
\hline Total R\&D / Sales & 0.25 & 0.14 & 0.76 \\
\hline $\begin{array}{l}\text { Goodwill amortization period } \\
\text { (years) }\end{array}$ & 12.32 & 9.77 & 0.02 \\
\hline \multicolumn{4}{|c|}{ Panel B: R\&D Descriptives on IFRS Sample } \\
\hline \multirow{4}{*}{\multicolumn{2}{|c|}{$\begin{array}{l}\text { firms with no new R\&D } \\
\text { firms with capitalized R\&D } \\
\text { firms with capitalized and expensed R\&D } \\
\qquad \text { total IFRS sample }\end{array}$}} & & 32 \\
\hline & & & 24 \\
\hline & & & 8 \\
\hline & & & 64 \\
\hline
\end{tabular}

Of the 108 companies included in the sample, 64 apply IFRS and consequently have the possibility to capitalize development costs. From Table 10, we conclude that capitalization of R\&D expenditures is commonly applied: 32 of the 64 IFRS companies either partly or fully capitalize their development costs (see Panel B). 


\subsection{Predictability OF EARNINGs}

To investigate whether the flexibility helps users to better predict future performance, we regress future performance on current year accounting information. In particular, we run a first-order autoregressive model (e.g., Lipe 1990) where next period's earnings (scaled by total sales) are the dependent variable and current year's earnings (also scaled by total sales) are included as independent variable ${ }^{23}$. In a first model, we restate earnings to be on an as-if expense basis $\left(\mathrm{X}_{\mathrm{t}}^{\mathrm{E}}\right)$. In a second model, we additionally introduce the change in earnings when capitalization is allowed (measured as the difference between $X_{t}^{C}$ and $X_{t}^{E}$ ) as a second explanatory variable. The models look as follows:

$$
\begin{aligned}
& \mathrm{OCF}_{\mathrm{i}, \mathrm{t}+1}=\alpha_{0}+\alpha_{1} \mathrm{X}_{\mathrm{it}}^{\mathrm{E}}+\varepsilon_{\mathrm{t}} \\
& \mathrm{OCF}_{\mathrm{i}, \mathrm{t}+1}=\alpha_{0}+\alpha_{1} \mathrm{X}_{\mathrm{it}}^{\mathrm{E}}+\alpha_{2}\left(\mathrm{X}_{\mathrm{it}}^{\mathrm{C}}-\mathrm{X}_{\mathrm{it}}^{\mathrm{E}}\right)+\varepsilon_{\mathrm{t}}
\end{aligned}
$$

where the models' R-square captures the predictive ability of current accounting information (see Van der Meulen et al. 2005). Given that capitalization under IFRS is only allowed when benefits are probable to flow to the enterprise, we expect model 11 to result in better predictions of future firm performance ${ }^{24}$.

Results from estimating these two models are presented in Panel A in Table 11. We find that including the $\left(\mathrm{X}_{\mathrm{it}}^{\mathrm{C}}-\mathrm{X}_{\mathrm{it}}^{\mathrm{E}}\right)$ term results in a significant parameter on this variable and in an adjusted $\mathrm{R}^{2}$ of $11 \%$. The reduced model, model 10 , is associated with an adjusted $\mathrm{R}^{2}$ of only $6 \%$. Further tests (Vuong 1989, Dechow 1994) on the models' $\mathrm{R}^{2}$ however suggest that the difference is not significant (Z-statistic= -0.99). In other words, although there is some indication of increased predictive ability, we cannot statistically conclude that flexibility better informs investors about future performance.

\footnotetext{
${ }^{23}$ Note that next period's earnings have also been restated to adjust for the annual amortization effect (of this year's capitalised R\&D). Based on hardcopy data concerning R\&D capitalisation and amortization period, we were able to estimate this annual amortization expense. Alternatively, we ran the analysis without amortization correction and obtained very similar results.

${ }^{24}$ Preliminary analyses of model 12 show that there is significant multicollinearity among the right hand side variables. For parameter estimation purposes, multicollinearity must be taken into consideration, however, for prediction purposes, multicollinearity typically has little impact (Verbeek 2000). This approach is similar to the one taken in Wysocki (2004).
} 
TABLE 11: MULTIVARIATE RESULTS ON THE PREDICTABILITY AND VALUE RELEVANCE OF IFRS STATED EARNINGS

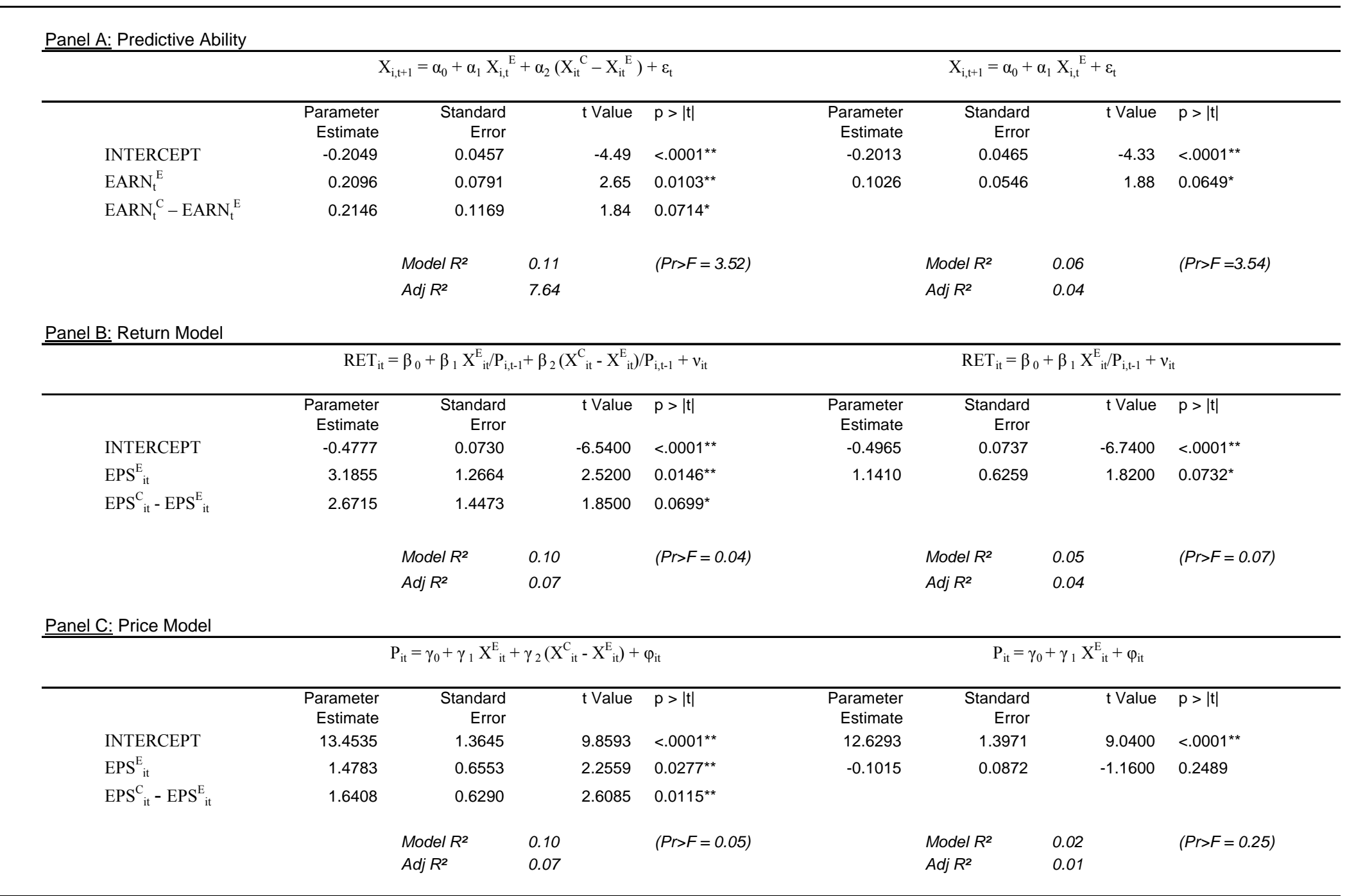

Note. To control for general market tendencies and price evolutions, we used year 2000 accounting data for all our firms (instead of the year of first time application).

${ }^{*},{ }^{* \star}=p$-value $<.10, .05$ respectively 


\subsection{VALUe RELEVANCE OF EARNings}

Next to the predictive ability of $R \& D$ capitalization, we also look at the value relevance of $R \& D$ capitalization. To examine this, we estimate both price and return models. As suggested by Kothari and Zimmerman (1995), estimating both has the potential to yield more convincing evidence. Results should then indicate whether the information that is additionally provided by offering more reporting flexibility is value relevant or not. In testing this value-relevance, we use similar techniques as Lev and Sougiannis (1996). For a large sample of R\&D expensers, Lev and Sougiannis estimate the R\&D capital by applying a sector specific amortization rate. They then adjust the reported earnings and book values for the $R \& D$ capitalization and introduce them in traditional return and price models, where they find that such adjustments are indeed value-relevant to investors. Our approach differs from that of Lev and Sougiannis in that we start from firms' actual R\&D capitalization rates and use this information to restate reported earnings to be on an as-if expense basis. Moreover, since the information on $\mathrm{R} \& \mathrm{D}$ capitalization is actually observed by investors, an association with prices/returns indicates that the information is value-relevant (and not that capitalization has the potential to be value-relevant, like in Lev and Sougiannis). The models are of the form:

$$
\begin{aligned}
& \mathrm{RET}_{\mathrm{it}}=\beta_{0}+\beta_{1} \mathrm{X}^{\mathrm{E}}{ }_{\mathrm{it}} / \mathrm{P}_{\mathrm{i}, \mathrm{t}-1}+\beta_{2}\left(\mathrm{X}^{\mathrm{C}}{ }_{\mathrm{it}}-\mathrm{X}_{\mathrm{it}}^{\mathrm{E}}\right) / \mathrm{P}_{\mathrm{i}, \mathrm{t}-1}+v_{\mathrm{it}} \\
& \mathrm{P}_{\mathrm{it}}=\gamma_{0}+\gamma_{1} \mathrm{X}_{\mathrm{it}}^{\mathrm{E}}+\gamma_{2}\left(\mathrm{X}_{\mathrm{it}}^{\mathrm{C}}-\mathrm{X}_{\mathrm{it}}^{\mathrm{E}}\right)+\varphi_{\mathrm{it}}
\end{aligned}
$$

where $\mathrm{RET}_{\text {it }}$ is the annual stock return starting nine months before fiscal $\mathrm{t}$ year-end till 3 months after, $\mathrm{X}^{\mathrm{C}}$ it and $\mathrm{X}^{\mathrm{E}}{ }_{\text {it }}$ are respectively reported and adjusted (or expensed) earnings-per-share (before extraordinary items) and $\mathrm{P}_{\mathrm{it}}$ is the share price of firm $\mathrm{i}$ at the end of the period.

In the above-mentioned models, stock returns (respectively share prices) are regressed on the level of earnings ${ }^{25}$. The adjustment to earnings, as-if all development costs would be expensed rather than capitalized, is singled out by the term $\left(\mathrm{X}^{\mathrm{C}}{ }_{\text {it }}-\mathrm{X}^{\mathrm{E}}{ }_{\text {it }}\right)$. Both models are run on a contemporaneous basis, thereby indicating the extent of current

\footnotetext{
${ }^{25}$ Both right-hand side earnings variables in model 12 are deflated by the firm's share price at the beginning of the fiscal year. In model 13, there is no price deflation. Therefore, we apply White's correction for heteroscedasticity.
} 
recognition of accounting numbers by investors. Since development costs may only be recognized as an asset "when it is probable that the future economic benefits will flow to the enterprise" (IASB Framework §89), we expect that the capitalization adjustment is positively correlated with stock prices and returns.

In Table 12, Panel $\mathrm{B}$ and $\mathrm{C}$, we present the results of the estimated models. Consistent with Lev and Sougiannis, we find that the capitalization adjustment, as captured by $\left(\mathrm{X}^{\mathrm{C}}{ }_{\mathrm{it}}-\mathrm{X}^{\mathrm{E}} \mathrm{it}\right)$, is positive $\left(\beta_{2}=2.6715\right)$ and significant $(\mathrm{p}=0.0699)$. In other words, information on $R \& D$ capitalization represents information that is relevant to investors in valuing a firm. That accounting data overall become more value relevant by adding information on capitalization, is also documented by comparing the R-squares of the reduced (with only expensed earnings per share) and full model (with both the expensed earnings and the capitalization adjustment). For the return models, this results in:

$$
\begin{aligned}
& \mathrm{RET}_{\mathrm{it}}=\beta_{0}+\beta_{1} \mathrm{X}_{\mathrm{it}}^{\mathrm{E}} / \mathrm{P}_{\mathrm{i}, \mathrm{t}-1}+v_{\mathrm{it}} \\
& \mathrm{RET}_{\mathrm{it}}=\beta_{0}+\beta_{1} \mathrm{X}_{\mathrm{it}}^{\mathrm{E}} / \mathrm{P}_{\mathrm{i}, \mathrm{t}-1}+\beta_{2}\left(\mathrm{X}_{\mathrm{it}}^{\mathrm{C}}-\mathrm{X}_{\mathrm{it}}^{\mathrm{E}}\right) / \mathrm{P}_{\mathrm{i}, \mathrm{t}-1}+v_{\mathrm{it}}
\end{aligned}
$$

As presented in column two of Table 14, the Adjusted R-square of the full model is higher than that of the reduced model (.07 compared to .04). Performing a Vuong test on the observed R-squares further results in a Z-statistic of respectively -3.383 and 1.349. Similar results are obtained for the price/earnings model. In sum, offering flexibility on R\&D does seem to result in more value relevant information. 


\section{SUMMARY}

Due to the increased competition on capital markets, a big number of markets and countries are currently offering firms the opportunity to depart from local standards and choose a different set of standards. As evidenced by previous findings, firms do not randomly pick their set of standards. Instead, the decision is well thought through, considering possible costs and benefits to the firm. Implementing new standards, for example, requires training of personnel, an adequate management information system... Possible benefits can be increased comparability and visibility and thereby, a lower cost of capital.

Relatively little attention has however been paid to specific differences between sets of standards. In this study, we addressed this void: we argued that if a transaction frequently occurs within a company and that transaction is treated differently under two sets of standards, this difference might influence the firm's standard set choice. The main proposition on which this study is based is that accounting differences between standards only matter in the standard choice when these differences are relevant to the firm. Therefore, we compare IFRS and US GAAP, 2 sets of standards that might be comparable in many respects, but still differ in accounting for some transactions.

Accordingly, we select three issues on which they differ and which are possibly relevant to our sample firms. A first difference is with regard to R\&D expenditures. As IFRS offers the possibility to capitalize development costs, while US GAAP requires immediate expensing, we hypothesize that R\&D intensive companies will opt for IFRS. Second area of interest is the area of business combinations. Given that US GAAP offers more flexibility on this issue, undertaking an acquisition is believed to be associated with US GAAP application. A third difference is with regard to employee share option plans, an item on which US GAAP is overall more demanding. Following the same reasoning, we hypothesize a negative relation between firms that award their employees with options and US GAAP choice. The results provide evidence consistent with our hypotheses: managers indeed opt for the standards set that provides most flexibility and demands least disclosures. Furthermore, we also found that offering firms more flexibility does not necessarily mean they use it. However, when taking advantage of the flexibility, it is used for the benefit of the investors, as it increases the value relevance of the accounting numbers. 
Our results are nonetheless subject to the following caveats. First, we address a very specific market of young and innovative firms. These new economy firms differ however in many respects from old economy firms and hence, it is not clear whether the results extend to the more mature firms in traditional industries. Secondly, we did not include all differences. As documented in the extensions section, the accounting item on which IFRS and US GAAP differ must be relevant to the firm. When addressing a different sample, other differences might therefore be more relevant. 


\section{APPENDIX 1: RELEVANT IFRS/US GAAP PASSAGES}

\section{Research and Development}

IAS 38

§42: No intangible asset arising from research (or from the research phase of an internal project) should be recognized. Expenditure on research (or on the research phase of an internal project) should be recognized as an expense when it is incurred.

§43: This standard takes the view that, in the research phase of a project, an enterprise cannot demonstrate that an intangible asset exists that will generate probable future economic benefits. Therefore, this expenditure is always recognized as an expense when it is incurred.

IAS 38- §45: An intangible asset arising from development (or from the development phase of an internal project) should be recognized if, and only if, an enterprise can demonstrate all of the following:

(a) the technical feasibility of completing the intangible asset so that it will be available for use or sale;

(b) its intention to complete the intangible asset and use or sell it;

(c) its ability to use or sell the intangible asset;

(d) how the intangible asset will generate probable future economic benefits. Among other things, the enterprise should demonstrate that the existence of a market for the output of the intangible asset or the intangible asset itself or, if it is to be used internally, the usefulness of the intangible asset;

(e) the availability to measure the expenditure attributable to the intangible asset during its development reliability.

§46: In the development phase of a project, an enterprise can, in some instances, identify an intangible asset and demonstrate that the asset will generate probable future economic benefits. This is because the development phase of a project is further advanced than the research phase.

§48: To demonstrate how an intangible asset will generate probable future economic benefits, an enterprise assesses the future economic benefits to be received from the asset using the principles in IAS 36, Impairment of Assets. If the asset will generate economic benefits only in combination with other assets, the enterprise applies the concept of cash generating units set out in IAS 36.

§49: Availability of resources to complete, use and obtain the benefits from an intangible asset can be demonstrated by, for example, a business plan showing the technical, financial and other resources needed and the enterprise's ability to secure those resources. In certain cases, an enterprise demonstrates the availability of the external finance by obtaining a lender's indication of its willingness to fund the plan. 
FAS 2

.108: All research and development costs encompassed by this section shall be charged to expense when incurred.

\section{$\underline{\text { Business Combinations }}$}

\section{IAS22}

9. In accounting for a business combination, an acquisition is in substance different from a uniting of interests and the substance of the transaction needs to be reflected in the financial statements. Accordingly, a different accounting method is prescribed for each.

10. In virtually all business combinations one of the combining enterprises obtains control over the other combining enterprise, thereby enabling an acquirer to be identified. Control is presumed to be obtained when one of the combining enterprises acquires more than one half of the voting rights of the other combining enterprise unless, in exceptional circumstances, it can be clearly demonstrated that such ownership does not constitute control.

13. In exceptional circumstances, it may not be possible to identify an acquirer. Instead of a dominant party emerging, the shareholders of the combining enterprises join in a substantially equal arrangement to share control over the whole, or effectively the whole, of their net assets and operations. In addition, the managements of the combining enterprises participate in the management of the combined entity. As a result, the shareholders of the combining enterprises share mutually in the risks and benefits of the combined entity. Such business combination is accounted for as a uniting of interests.

17. A business combination, which is an acquisition, should be accounted for by use of the purchase method of accounting as set out in the standards contained in paragraphs 19 to 76 .

43. Goodwill should be carried at cost less any accumulated amortization and any accumulated impairment losses.

44. Goodwill should be amortized on a systematic basis over its useful life. The amortization period should reflect the best estimate of the period during which future economic benefits are expected to flow to the enterprise. There is a rebuttable presumption that the useful life of goodwill will not exceed twenty years from initial recognition.

\section{APB 16}

.102 Some combinations shall be accounted for by the purchase method and other combinations shall be accounted for by the pooling-of-interests method. The two methods are not alternatives in accounting for the same business combination. A single method shall be applied to an entire combination; the practice known as part-purchase, part-pooling is not acceptable. The acquisition of some or all of the stock held by minority stockholders of a subsidiary shall be accounted for by the purchase method rather than by the pooling-ofinterest method. 
.103 The distinctive conditions that require pooling-of-interest accounting are described in paragraphs .104 through .107 and combinations involving all of those conditions shall be accounted for as described in paragraphs .109 through .124. All other business combinations shall be treated as the acquisition of one enterprise by another and accounted for by the purchase method as described in paragraphs .125 through .166.

.104 The pooling-of-interests method of accounting is intended to present as a single interest two or more common stockholder interests that were previously independent and the combined rights and risks represented by those interests. [...] A business combination that meets all of the conditions specified and explained in paragraphs .105 through .107 shall be accounted for by the pooling-of-interest method. The conditions are classified by (a) attributes of the combining enterprises, (b) manner of combining interests, and (c) absence of planned transactions.

$.105[\ldots]$ (a) Each of the combining enterprises is autonomous and has not been a subsidiary or division of another enterprise within two years before the plan of combination is initiated.

(b) Each of the combining enterprises is independent of the other combining enterprises.

.106 The combining of existing voting common stock interests by the exchange of stock is the essence of a business combination accounted for by the pooling-of-interests method.

APB 17

.110 The period of amortization shall not, however, exceed 40 years. Analysis at the time of acquisition may indicate that the indeterminate lives of some intangible assets are likely to exceed 40 years and the cost of those assets shall be amortized over the maximum period of 40 years, not an arbitrary shorter period.

\section{Employee Stock Option Plans}

\section{IAS 19}

145. This standard does not specify recognition and measurement requirements for equity compensation benefits.

152. In the absence of specific recognition and measurement requirements for equity compensation plans, information about the fair value of the reporting enterprise's financial instruments used in such plans is useful to users of financial statements. However, because there is no consensus on the appropriate way to determine the fair value of share options, this standard does not require an enterprise to disclose their fair value.

147. An enterprise should disclose:

(a) the nature and terms (including any vesting provisions) of equity compensation plans;

(b) the accounting policy for equity compensation plans;

(c)the amounts recognized in the financial statements for equity compensation plans; ... 


\section{APB 25}

.110

Compensation for services that an employer receives as consideration for stock issued through employee stock option, purchase, and award plans shall be measured by the quoted market price of the stock at the measurement date less the amount, if any, that the employee is required to pay.

.123

Paragraphs .144 through .147 of Section C36 specify the disclosures related to stock based employee compensation arrangements that shall be made in the financial statements. 
APPENDIX 2: ROBUSTNESS TESTS FOR THE MULTIVARIATE MODEL

\begin{tabular}{|c|c|c|c|c|c|c|c|c|c|c|}
\hline \multirow[b]{2}{*}{ Variable } & \multicolumn{2}{|c|}{ Model 3} & \multicolumn{2}{|c|}{ Model 4} & \multicolumn{2}{|c|}{ Model 5} & \multicolumn{2}{|c|}{ Model 6} & \multicolumn{2}{|c|}{ Model 7} \\
\hline & $\begin{array}{c}\text { Parameter } \\
\text { Estimate }\end{array}$ & $\begin{array}{r}p< \\
\text { (ChiSQ) }\end{array}$ & $\begin{array}{c}\text { Parameter } \\
\text { Estimate }\end{array}$ & $\begin{array}{r}p< \\
\text { (ChiSQ) }\end{array}$ & $\begin{array}{c}\text { Parameter } \\
\text { Estimate }\end{array}$ & $\begin{array}{r}p< \\
\text { (ChiSQ) }\end{array}$ & $\begin{array}{c}\text { Parameter } \\
\text { Estimate }\end{array}$ & $\begin{array}{r}\mathrm{p}< \\
\text { (ChiSQ) }\end{array}$ & $\begin{array}{c}\text { Parameter } \\
\text { Estimate }\end{array}$ & $\begin{array}{r}p< \\
\text { (ChiSQ) }\end{array}$ \\
\hline INTERCEPT & -1.0042 & 0.7081 & -1.3130 & 0.6184 & -1.3053 & 0.6284 & -0.5841 & 0.8349 & -0.2641 & 0.9173 \\
\hline $\mathrm{RD}$ & -1.1434 & 0.0595 * & -0.8874 & 0.1326 & -1.0848 & 0.0754 * & -0.8138 & 0.1389 & -1.3187 & 0.0337 ** \\
\hline ACQ & & & 0.9542 & 0.0925 * & 0.9806 & 0.0931 * & 1.0954 & 0.0673 * & 0.9767 & 0.0869 * \\
\hline$A C Q_{L T}$ & 0.6210 & 0.3242 & & & & & & & & \\
\hline EMPRIOR & -0.9235 & 0.0799 * & -0.9913 & 0.0514 ** & -0.9984 & 0.0547 ** & -0.8824 & 0.1009 * & -0.8909 & 0.0862 * \\
\hline SALES & -0.0838 & 0.7140 & -0.0487 & 0.8292 & -0.0648 & 0.7775 & -0.1720 & 0.4708 & -0.1524 & 0.4959 \\
\hline FLOAT & 0.0193 & 0.1238 & 0.0211 & $0.0872 *$ & 0.0174 & 0.1783 & 0.0215 & $0.0898 *$ & 0.0207 & 0.1139 \\
\hline FOREIGN & 1.7112 & $0.0172 * *$ & 1.3946 & 0.0351 ** & 1.7295 & 0.0166 ** & 1.6928 & 0.0187 ** & 1.9710 & 0.0055 ** \\
\hline INCSTOCK & -2.0564 & $0.0086 * \star$ & & & -2.1381 & 0.0066 ** & -2.2768 & 0.0034 ** & -2.1371 & $0.0055 * *$ \\
\hline DSTOCK & & & -0.8777 & $0.0891 *$ & & & & & & \\
\hline DEBT & 0.1507 & 0.3496 & 0.0831 & 0.4608 & & & 0.1330 & 0.3725 & 0.1074 & 0.3803 \\
\hline STDEBT & & & & & 0.0752 & 0.2339 & & & & \\
\hline PERF & -0.5656 & 0.3285 & -0.7999 & 0.1894 & -0.6144 & 0.5920 & & & -0.6521 & 0.2745 \\
\hline CASHFLOW & & & & & & & -0.0826 & 0.8606 & & \\
\hline INDUSTRY & 0.9880 & 0.0689 * & 0.9164 & 0.0774 * & 1.1127 & 0.0396 ** & 1.0700 & 0.0514 ** & & \\
\hline \multirow[t]{4}{*}{ MANUFACT } & & & & & & & & & -0.5548 & 0.2920 \\
\hline & Model $\chi^{2}$ & 32.70 ** & Model $\chi^{2}$ & $27.77^{\star \star}$ & Model $\chi^{2}$ & 29.61 ** & Model $\chi^{2}$ & $33.85 * *$ & Model $\chi^{2}$ & 32.55 ** \\
\hline & Pseudo-R ${ }^{2}$ & 0.29 & Pseudo-R ${ }^{2}$ & 0.23 & Pseudo- $\mathbf{R}^{2}$ & 0.27 & Pseudo-R ${ }^{2}$ & 0.31 & Pseudo-R ${ }^{2}$ & 0.29 \\
\hline & Concordant & $77.2 \%$ & Concordant & $76.8 \%$ & Concordant & $78.6 \%$ & Concordant & $79.7 \%$ & Concordant & $78.2 \%$ \\
\hline
\end{tabular}


APPENDIX 3: PEARSON CORRELATION COEFFICIENTS FOR THE INDEPENDENT VARIABLES IN THE CHOICE MODEL

\begin{tabular}{|c|c|c|c|c|c|c|c|c|c|c|}
\hline & RD & ACQ & EMPRIOR & SALES & FLOAT & FOREIGN & INCSTOCK & PERF & DEBT & INDUSTRY \\
\hline RD & 1 & -0.0777 & 0.0462 & -0.1985 & 0.1042 & 0.2916 & -0.0602 & -0.2867 & -0.0122 & -0.0305 \\
\hline ACQ & & 1 & -0.0993 & -0.0006 & -0.0347 & -0.0342 & 0.1666 & 0.0497 & 0.0741 & 0.0023 \\
\hline EMPRIOR & & & 1 & -0.0226 & -0.0376 & -0.0699 & 0.0092 & 0.0257 & -0.1238 & 0.1777 \\
\hline SALES & & & & 1 & -0.1317 & -0.0234 & -0.0251 & 0.3994 & -0.1108 & -0.2811 \\
\hline FLOAT & & & & & 1 & 0.0618 & 0.0256 & -0.1317 & 0.0648 & -0.1172 \\
\hline FOREIGN & & & & & & 1 & 0.0483 & 0.0534 & 0.1902 & 0.1344 \\
\hline INCSTOCK & & & & & & & 1 & 0.1075 & 0.0099 & 0.0709 \\
\hline PERF & & & & & & & & 1 & -0.0437 & -0.1479 \\
\hline DEBT & & & & & & & & & 1 & 0.1902 \\
\hline INDUSTRY & & & & & & & & & & 1 \\
\hline
\end{tabular}




\section{REFERENCES}

Aboody, D. and Lev, B. (1999). 'The value-relevance of intangibles: The case of software capitalization.' Journal of Accounting Research, 36(suppl.): 161-191.

Anderson, M., Banker, R. and Ravindran, S. (2000). 'Executive compensation in the information technology industry.' Management Science, 46(4): 530-547.

Ang, J., Cole, R. and Lin, J. (2000). 'Agency cost and ownership structure.' Journal of Finance, 55(1): 81-106.

Ashbaugh, H. (2001). 'Non-US firms' accounting standard choices.' Journal of Accounting and Public Policy, 20(2): 129-153.

Ashbaugh, H. and Pincus, M. (2001). 'Domestic accounting standards, international accounting standards, and predictability of earnings.' Journal of Accounting Research, 39(3): 417-434.

Brown, L. (1983). 'Accounting changes and the accuracy of analysts' earnings forecasts.' Journal of Accounting Research, 21(2): 432- 450.

Cuijpers, R., Buijink, W. and Maijoor, S. (2002). 'Voluntary adoption of non-local GAAP in the European Union: A study of determinants.' Working Paper Series.

Dechow, P., Kothari, S. and Watts, R. (1998). 'The relation between earnings and cash flows.' Journal of Accounting and Economics, 25(2): 133-168.

Dechow, P. (1994). 'Accounting earnings and cash flows as measures of firm performance: The role of accounting accruals.' Journal of Accounting and Economics, 18(1): 3-42.

Dumontier, P. and Raffournier, B. (1998). 'Why firms comply voluntarily with IAS: An empirical analysis with Swiss data.' Journal of International Financial Management and Accounting, 9(3): 216-245.

El-Gazzar, S., Finn, P. and Jacob, R. (1999). 'An empirical investigation of multinational firms compliance with IAS.' The International Journal of Accounting, 34(2): 239-248.

Elliott, J. and Philbrick, D. (1990). 'Accounting changes and earnings predictability.' Accounting Review, 65(1):157-175.

Ernst\&Young (2002). IAS/US GAAP comparison: A comparison between IAS and US accounting principles.

Bloomer, C. (1999). The IASC-U.S. comparison project: A report on the similarities and differences between IASC Standards and U.S. GAAP. Norwalk, Connecticut.

Fishman, M. and Hagerty, K. (1990). 'The optimal amount of discretion to allow in disclosure.' Quarterly Journal of Economics, 105(2):427-445.

Hirst, D. and Hopkins, P. (1998). 'Comprehensive income reporting and analysts' valuation judgments.’ Journal of Accounting Research, 36(suppl): 47-75.

Hunton, J., Libby, R. and Mazza, C. (2004). 'Financial reporting transparency and earnings management.' Working Paper Series.

Ittner, C., Lambert, R. and Larcker, D. (2003) 'The structure and performance consequences of equity grants to employees of new economy firms.' Journal of Accounting and Economics, 34(1-3): 89-127.

Jensen, M. (1986). 'Agency costs of free cash flow, corporate finance, and takeovers.' American Econmic Review, 76(2): 323-329.

Joos, P. and Lang, M. (1994). 'The effects of accounting diversity: Evidence from the European Union.' Journal of Accounting Research, 32(3): 141-169. 
Jung, K. and Kwon, S. (2002). 'Ownership structure and earnings informativeness: Evidence from Korea.' International Journal of Accounting, 37(3): 301-325.

Koh, P. (2003). 'On the association between institutional ownership and aggressive corporate earnings management in Australia.' British Accounting Review, 35(2): 105-129.

Kothari, S and Zimmerman, J. (1995). 'Price and return models.' Journal of Accounting and Economics, 20(2): 155-192.

KPMG (2000). 'Global financial reporting: IAS or US GAAP?' European Survey Report.

Lang, M., Raedy, J. and Yetman, M. (2003). 'How representative are firms that are crosslisted in the United States? An analysis of accounting quality.' Journal of Accounting Research, 41(2): 363-386.

Leuz, C. (2003). 'IAS versus US GAAP: Information-asymmetry based evidence from Germany's new market.' Journal of Accounting Research, 41(3): 445-472.

Leuz, C., Nanda, D. and Wysocki, P. (2003). 'Earnings management and investor protection: An international comparison.' Journal of Financial Economics, 69(3): 505-527.

Lev, B. and Sougiannis, T. (1996). 'The capitalization, amortization, and value-relevance of R\&D.' Journal of Accounting and Economics, 21(1): 107-138.

Maloney, M., McCormick, R. and Mitchell, M. (1993). 'Managerial decision making and capital structure.' Journal of Business, 66(2): 189-217.

Meuwissen, R., Moers, F., Peek, E. and Vanstraelen, A. (2004). 'An evaluation of abnormal accruals measurement models in an international context.' Working Paper Series.

Milgrom, P. (1981). 'Good news and bad news: Representation theorems and applications.' Bell Journal of Economics, 12(2): 380-392.

Milgrom, P. and Roberts, J. (1986). 'Price and advertising signals of product quality.' Journal of Political Economy, 94(4): 796-821.

Murphy, K. (2003). 'Stock-based pay in new economy firms.' Journal of Accounting and Economics, 34(1-3): 129-147.

Pound, J. (1988). 'Proxy contests and the efficiency of shareholder oversight.' Journal of Financial Economics, 20: 237-265.

Shleifer, A. and Vishney, R. (1986). 'Large shareholders and corporate control.' Journal of Political Economy, 94(3): 461-488.

Van der Meulen, S., Gaeremynck, A. and Willekens, M. (2005). 'Attribute Differences between US GAAP and IFRS Earnings: an Exploratory study.' KUL Research Report.

Verbeek, M. (2000). Modern econometrics. Wiley, West Sussex.

Verrecchia, R. (1983). 'Discretionary disclosure.' Journal of Accounting \& Economics, 5(3): 179-194.

Verrecchia, R. (2001). 'Essays on disclosure.' Journal of Accounting \& Economics, 32(1-3): 97-180.

Vuong, Q. (1989). 'Likelihood ratio tests for model selection and non-nested hypotheses.' Econometrica, 57(2): 307-333.

Wong, S., Opper, S. and Hu, R. (2004). 'Shareholding structure, depoliticization and firm performance: Lesson from China's listed firms.' Economics of Transition, 12(1): 29-66.

Wysocki, P. (2004). 'Assessing earnings and accrual quality: US and international evidence.' Working Paper Series. 